\title{
Bioerosion and availability of shelter for benthic reef organisms
}

\author{
David P. Moran*, Marjorie L. Reaka** \\ Department of Zoology, University of Maryland, College Park, Maryland 20742, USA
}

\begin{abstract}
Bioerosion was examined in 5 different reef habitats on the northeast of St Croix, USVI, and the hypothesis tested that cavities provided by borers govern the numbers and body sizes of an important motile cryptobiont, stomatopod crustaceans. Bioeroders excavated significant percentages of material from beachrock or dead coral substrates in the intertidal zone $(0 \mathrm{~m})$, fringing reef $(-1 \mathrm{~m})$, lagoonal patch reef $(-3 \mathrm{~m})$, and the back reef $(-3 \mathrm{~m})$ and fore reef $(-12 \mathrm{~m})$ of the offshore barrier reef. Mean volumes removed were 8.4 to $18.3 \%$ among habitats (range 0.1 to $32.9 \%$ for individual rocks). Overall bioerosion was not correlated with depth, and was greatest on the patch reef. Results confirm that bioerosion is more intensive in Caribbean than western Pacific waters, and are consistent with the hypothesis that primary productivity governs the biogeographic impact of bioeroders. Average hole sizes were largest in the intertidal and on the fringing reef. Total numbers of cavities appropriate for stomatopods were greatest on the patch reef, intermediate on the fore, back and fringing reefs, and least in the intertidal. Stomatopod body sizes were largest in the intertidal and declined toward the offshore reef, congruent with the sizes of holes in these habitats. Also, the intertidal zone was inhabited by significantly fewer stomatopods than the fringing, patch and back reefs. There was no tendency, however, towards unusually high densities in the particularly abundant small holes of the patch reef. We conclude that sizes and to a lesser extent numbers of stomatopods are generally correlated with sizes and numbers of cavities available, although other factors (predation in subtidal habitats, storms in shallow habitats) sometimes influence population characteristics (especially densities). Consequently, the sizes of cavities available likely limit the body sizes of reef stomatopods, in contrast to those that excavate enlargeable burrows in soft bottoms, and biogeographic trends in their body sizes may be attributable to the sizes of cavities pruvided by bioeroders. The sessle and particularly the motile cryptofauna represents an understudied but critically important component of the coral reef community, and boring organisms are prerequisite for its development. Fast and efficient predators evolved in the Mesozoic concurrently with scleractinian corals, Iarge carbonate reefs and bioeroding organisms. We suggest that boring habits protected early bioeroders from predators and provided crypts, into which radiated a vast assemblage of benthic reef biota. This crytofauna was in turn molded by predation and thence competition for refuges. Thus, predation likely exerted a cascading effect upon the diversity and structure of coral reef communities via bioerosion and the availability of shelter for benthic reef organisms.
\end{abstract}

\section{INTRODUCTION}

Organisms that burrow into carbonate for a place to live (Carriker \& Smith 1969) include bacteria, algae, fungi, sponges, polychaetes, sipunculans, thoracian and acrothoracican barnacles, bivalves, gastropods, echinoids, and crustaceans. In most studies that have examined the relative importance of various reef macroburrowers, sponges were the most important in both live coral and dead coral rubble. Grazing urchins and

\footnotetext{
- Present address: National Wetlands Research Center, US Fish \& Wildlife Service, 1010 Gause Blvd, Slidell, Louisiana 70458, USA

- Addressee for reprint requests
}

fishes also can remove substantial quantities of reef substrate (Davies 1983, Hutchings 1986, Reaka et al. unpubl.).

Bioerosion (the removal of rock substrate by an organism due to digestion of the organic matrix, secretion of acid that dissolves $\mathrm{CaCO}_{3}$ and/or mechanical abrasion; Neumann 1966) destroys coral skeletons and other carbonate rocks and can reduce them to sand. Breakdown of sand to silt is continued by endolithic algae in protected areas and by abrasion in areas of strong wave action (Swinchatt 1965). Quantitative estimates of overall rates of bioerosion have been calculated for some carbonate coastlines, for certain coral substrates, and for several macroburrowing taxa on 
reefs (e.g. Davies 1983, Spencer 1985, Hutchings 1986, Reaka et al. unpubl.). In addition, several studies now provide comparative information on the extent of bioerosion in different biogeographic regions, in particular for bioeroders of live coral substrates in West Atlantic and Indo-West Pacific regions (Hein \& Risk 1975, Bak 1976, MacGeachy \& Stearn 1976, MacGeachy 1977, Scoffin et al. 1980, Highsmith 1980a, 1981, Risk \& Sammarco 1982, Highsmith et al. 1983). Highsmith (1981) also has quantified bioerosion in dead coral rubble from the mid-Pacific. The present study provides the first comparative information on the extent of bioerosion in West Atlantic dead coral rubble substrates.

The amount of bioerosion on reefs is significant not only for understanding the structural dynamics of current and fossil reef systems (Scoffin 1972, Adey 1978, Scoffin et al. 1980, Davies 1983, Adey \& Steneck 1985, Spencer 1985, Hubbard 1986. Hutchings 1986, Reaka et al. unpubl.), but also because the cryptic organisms that inhabit the holes formed by bioeroders comprise a major component of the biomass and diversity of the coral reef ecosystem. The hard substrate surrounding boring organisms and subsequent cryptic colonizers protects them from the pervasive predatory fishes on reefs, and in some areas (such as the intertidal zone) from physical stress. Jackson and his co-workers (Jackson \& Buss 1975, Jackson 1977) have documented high species diversity, competition for space, and low levels of predation and disturbance among sessile organisms in cryptic reef habitats. Compared to the sessile cryptofauna and the conspicuous sessile epibiota (corals, sponges) and fishes on reefs, however, the abundant motile cryptofauna has received remarkably little study. The present study examines the extent of bioerosion in 5 major reef habitats in St Croix, US Virgin Islands, with specific reference to the size and density of one of the major motile organisms in the cryptic reef habitat - stomatopod crustaceans.

Except for the much rarer octopuses, stomatopods are the top predators in these benthic communities. Mantis shrimps exhibit intense fighting and territorial behavior (Caldwell \& Dingle 1975, Reaka \& Manning 1981). Burrows (bioeroded holes in rubble or beachrock) serve as shelter from fish predation and physical stress, and provide an essential lair in which to mate and molt (Dingle \& Caldwell 1972, Reaka 1975, 1976, 1979a, 1980a, Reaka et al. 1987). Many other motile cryptic species (especially the alpheid, thalassinid and axiid shrimps; most of the crabs; even the rock-boring urchin Echinometra lucunter) show similar intense agonistic behavior (Grunbaum et al. 1978, Reaka 1987), and cryptic reef ophiuroids partition refuge space among species (Sides \& Woodley 1985). Thus, competition for spatial resources has been thought to limit many motile cryptic reef populations (Reaka 1980b, 1985, Reaka \& Manning 1981. Sides \& Woodley 1985, Steger 1987), as it does the sessile cryptobiota (Jackson \& Buss 1975). We use stomatopods Gonodactylus bredini, G. oerstedii, and G. spinulosus as an example in the present study, but our studies and observations suggest that many of the larger species of motile cryptofauna may show similar patterns.

This study provides some of the first comparative data on the size frequency distributions of the crevices that are inhabited by cryptic organisms such as stomatopods in different reef habitats. If the number of cavities of appropriate size in substrates from different habitats is correlated with numbers and sizes of cryptic organisms, these data would not prove but would be consistent with the hypothesis that the availability of spatial refuges limits densities of cryptic reef organisms. Alternatively, if there is no such correlation, then other factors must determine the densities of these species.

Several of the following observations suggest that spatial refuges become increasingly limiting for larger members of the motile cryptic reef biota. In stomatopods, levels of aggression increase with body size within and among coral-dwelling species (Reaka \& Manning 1981). Also, stomatopod species that excavate their own burrows in soft bottoms reach much greater body sizes (to $>350 \mathrm{~mm}$ in length) than those restricted to preformed holes in hard substrates (where no species exceeds $150 \mathrm{~mm}$ in length). Reaka (1986a) has proposed that the lack of large holes may prevent rockand reef-dwelling stomatopods from attaining body sizes as large as those from soft bottoms. Similarly, coral-dwelling stomatopods reach larger adult body sizes in the western Atlantic than in the eastern Pacific region (Reaka 1986a). One possible explanation is that, due to the activities of bioeroders, the sizes of burrows are less restrictive for western Atlantic than eastern Pacific species. The factors that constrain body size are of critical significance for both the ecology and evolution of these organisms, since life history and dispersal patterns, as well as evolutionary rates, are highly correlated with adult body size (Reaka 1979a,b, 1980c, 1986a, Reaka \& Manning 1981, 1987a). The present study, then, allows us to evaluate and possibly refute the hypothesis that the size of available burrows limits the maximum sizes and evolutionary characteristics of benthic reef organisms such as stomatopods.

Lastly, many biological processes (including predation, bioturbation and bioerosion) have been shown to have increased in intensity over geological time, in particular during and since the Mesozoic (Vermeij 1978, Thayer 1979, Palmer 1982). If a correlation between bioerosion and the size and number of cryptic reef organisms can be demonstrated, then it follows that the substantial increase in available habitat due to 
the proliferation may have allowed radical increases in the diversity of this important cryptic reef biota during the Mesozoic.

\section{METHODS}

Study sites. We studied 5 relatively shallow reef habitats in St Croix, US Virgin Islands (Fig. 1). The study sites included the intertidal beachrock zone of Boiler Bay (IBZ), the subtidal fringing reef of Boiler Bay (SFR), a patch reef in the lagoon of Tague Bay (PR), and the back reef (BR) and fore reef (FR) of the bank barrier reef enclosing Tague Bay. Depths at low tide were approximately $0 \mathrm{~m}$ (IBZ), $-1 \mathrm{~m}$ (SFR), $-3 \mathrm{~m}$ (PR), $-3 \mathrm{~m}$ (BR), and $-12 \mathrm{~m}$ (FR).

Sampling and measurements. In summer 1980, we collected representative pieces of beachrock or massive coral rubble (ca $10 \times 15 \times 25 \mathrm{~cm}$ height, width, length for both beachrock and rubble; hereafter these will usually be termed 'rocks') at $10 \mathrm{~m}$ intervals along $100 \mathrm{~m}$ transects established parallel to the shoreline. The piece of coral rubble nearest each $10 \mathrm{~m}$ mark was selected or, in the case of the intertidal habitat, a piece of beachrock at the $10 \mathrm{~m}$ mark was chiselled from the substrate. To standardize the coral rubble samples, only dead massive heads were collected. Because Montastrea annularis is one of the most abundant coral species in these environments, most of the pieces were probably derived from this species, although the origi- nal species indentities were unrecognizable. All rocks used in the analysis of bioerosion were weighed (damp dry) except for 2 on the fore reef, for which a scale was not available during collection. The rocks were sawed in half longitudinally with a diamond rock saw. The holes in the cut surface of each rock half were either copied on a copying machine (with a correction applied for the slight change in size) or were traced directly onto plexiglass and then onto paper. For each rock half, the data included only bored holes and not irregularities at the edge of the rock where the indentation was less than hemispherical. Each rock half was only about $5 \mathrm{~cm}$ thick (comprising the $10 \mathrm{~cm}$ height, above), and all holes connected to the surface of the rock. Rocks from the 5 habitats were not significantly different in size, as indicated by their cross-sectional area. Possibly because they were derived from denser substrate or because they were subject to less extensive bioerosion, rock samples from the intertidal zone were heavier than those from the fore reef (Table 1).

The extent of bioerosion was determined firstly by calculating the total percentage of the cross-sectional area that was bored. Both the total area of the cut surface and the areas of the holes were measured with a planimeter. It was not possible to accurately measure the area of holes less than $20 \mathrm{~mm}^{2}$ (diameter ca $5 \mathrm{~mm}$ ) with the planimeter, and thus measurement of the \% bioerosion did not include these very small holes.

Secondly, we measured the availability of space by quantifying the diameters of holes. The distance per-

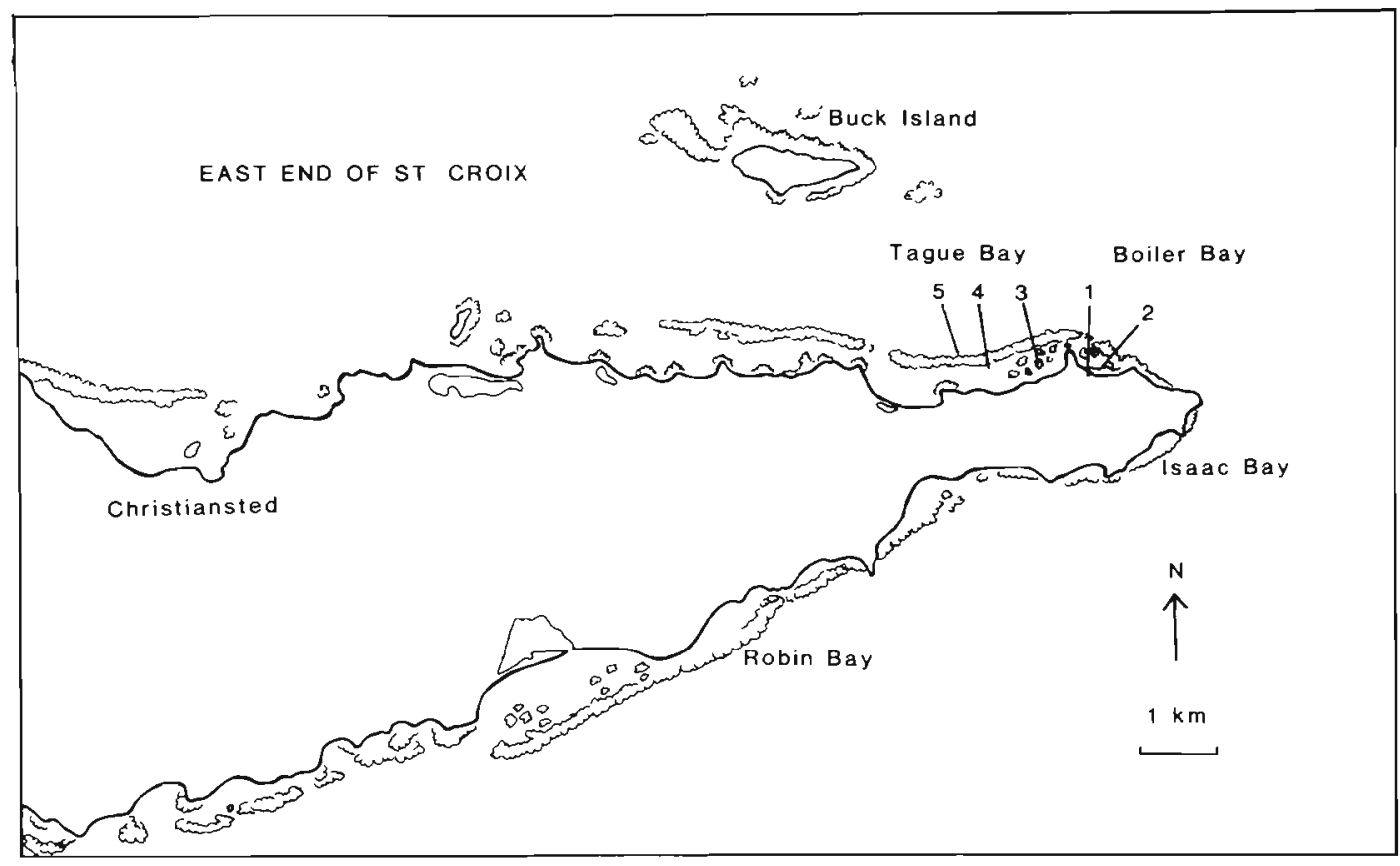

Fig. 1. Study sites on the northeast side of St Croix, US Virgin Islands. 1: Boiler Bay intertidal beachrock zone; 2: Boiler Bay subtidal fringing reef; 3 : patch reef in Tague Bay; 4: site on the back side of the bank barrier reef enclosing Tague Bay; 5 : site at the base of the fore reef on the outside of Tague Bay 
Table 1. Cross-sectional area and weight of rocks from different habitats. Data were analysed by ANOVA. For area, $F_{4,45}=1.84 ;$ after square root transformation $\left([Y+1]^{0.5}\right), F-\max _{5,9}=5.41$. For weight, $F_{4,43}=4.57^{\cdots}$; after negative square root transformation $\left([\mathrm{Y}+1]^{-0.5}\right), F-\max _{59}=6.76$. Arithmetic means and back-transformed $95 \%$ confidence intervals (CI) are given. For rock mass, each mean of a pair without a common superscript is significantly different from the other at $p<0.05$ by a Duncan's multiple range test. For all treatments, $N=10$ except only 8 weights were available for the 10 rocks from the fore reef (see text)

\begin{tabular}{llccc|}
\hline Habitat & \multicolumn{2}{c}{ Cross-sectional area $\left(\mathrm{cm}^{2}\right)$} & \multicolumn{2}{c}{ Rock mass $(\mathrm{kg})$} \\
& $\overline{\mathrm{Y}}$ & $95 \% \mathrm{Cl}$ & $\overline{\mathrm{Y}}$ & $95 \% \mathrm{Cl}$ \\
\hline Intertidal zone & 292 & $(201-372)$ & $6.4^{\mathrm{b}}$ & $(3.28-8.95)$ \\
Fringing reef & 208 & $(176-239)$ & $3.6^{\mathrm{ab}}$ & $(2.50-4.57)$ \\
Patch reef & 230 & $(190-275)$ & $2.7^{\mathrm{ab}}$ & $(1.84-3.22)$ \\
Back reef & 258 & $(207-305)$ & $3.7^{\mathrm{ab}}$ & $(2.51-4.71)$ \\
Fore reef & 212 & $(171-251)$ & $2.3^{\mathrm{a}}$ & $(1.16-3.34)$ \\
\hline
\end{tabular}

pendicular to the long axis of each hole was recorded as the diameter, since the minimal width of the hole is most significant for an animal resident. For the intertidal beachrock area, hole diameter was measured with Vernier calipers with an accuracy of $\pm 0.1 \mathrm{~mm}$. Since the manual caliper measurements were very time-consuming, for the other habitats we used calipers connected to an Apple microcomputer (with an accuracy of $\pm 0.6 \mathrm{~mm}$ ) to measure holes up to $20 \mathrm{~mm}$ in diameter (the size limit for this equipment). Holes greater than $20 \mathrm{~mm}$ in diameter were measured with a ruler to the nearest $\mathrm{mm}$. In contrast to the measurements for \% bioerosion, we used the diameters of all holes (including those $<5 \mathrm{~mm}$ ) for these sizes frequency analyses.

To quantify the number of stomatopods and other cryptofauna per rock (Reaka \& Manning 1987b), 10 rock samples were taken in all 5 habitats along the transects described above in summer 1980 (July), winter 1980-81 (January), and summer 1981 (July). Rocks were placed into plastic bags and sealed in situ. In a dishpan on shore, each rock was chiselled into pieces 1 to $2 \mathrm{~cm}$ in diameter. The pieces were rinsed in seawater and then in $70 \%$ alcohol. All visible animals were removed and preserved. The seawater, alcohol solution and small particles were sieved through a 0.70 mm sieve. After sieving, all material was preserved with $50 \%$ formalin (diluted to 10 to $20 \%$ by seawater in the sample) and stained with Rose Bengal. As many animals as possible were removed from the preserved pebble substrate with a bubbling tube elutriator (Stewart 1975). Both the elutriated and the remaining substrate were examined under a dissecting microscope.

The body lengths (rostrum to tip of telson) of all stomatopods from the transects above were measured with a ruler to the nearest $\mathrm{mm}$. To increase sample sizes for body size, additional rocks were sampled from haphazardly arranged plots or transects in the intertidal zone, fringing reef, patch reef and back reef habitats in the summers of 1979 and 1980 , and from the fringing, patch, back and fore reefs in the summer of 1981 .
Statistics. Area of substrate excavated: We determined the extent of bioerosion in the various habitats with a Model I ANOVA on the \% area excavated from cross sections of each rock (calculated as total area of holes/total area of cross section $\times 100$ ). This is an estimate of the \% volume removed from a cross section of constant thickness because both the total volume and volume removed can be obtained by multiplying the respective areas by the thickness. Each datum for this ANOVA was the mean of the 2 cut surfaces (halves) of each respective rock. If the ANOVA was significant, a Duncan's multiple range test was planned. In these and all subsequent cases, assumptions of homogeneity of variance were tested with a $F$-max test and the results presented.

Size frequencies of holes: Differences in mean hole sizes among the 5 habitats were analysed with a 1 -way ANOVA and a Duncan's multiple range test. Only holes 5.05 to $35.05 \mathrm{~mm}$ in diameter, the approximate range suitable for stomatopod occupation (Fig. 2), were used. The total number of holes rock ${ }^{-1}$ in the size range 5.05 to $35.05 \mathrm{~mm}$ also was analysed by a 1-way ANOVA among habitats and a Duncan's multiple range test.

In addition, differences in the frequencies of holes in different size classes among habitats were measured with 1 -way analyses of variance on hole size, with tests for each of the following 7 classes of the hole diameter: 0.00-5.05 mm, 5.06-10.05 $\mathrm{mm}, 10.06-15.05 \mathrm{~mm}$, 15.06-20.05 mm, 20.06-25.05 mm, 25.06-30.05 mm, and $>30.05 \mathrm{~mm}$. Duncan's multiple range tests were used when appropriate. The 10.06-15.05 $\mathrm{mm}$ class demanded a Kruskal-Wallis test because variances could not be homogenized. If the Kruskal-Wallis test was significant, pairwise Mann-Whitney $U$-tests adjusted for multiple comparisons were planned. Data were grouped into size classes $5 \mathrm{~mm}$ in width prior to analysis. We also evaluated the availability of holes in the different habitats with $\chi^{2}$ contingency tables that tested whether or not the proportion of holes in different size classes was similar among habitats, but these 


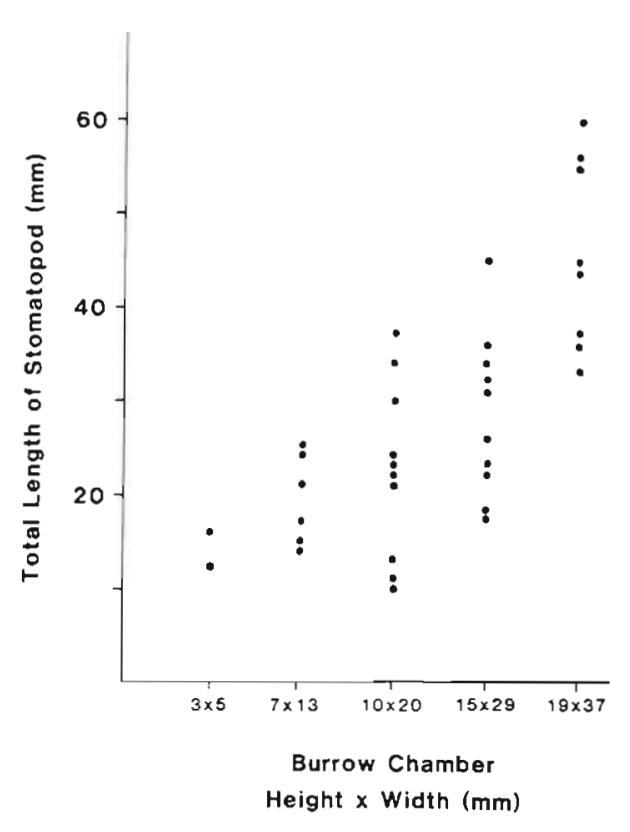

Fig. 2. Stomatopod length vs size of burrow selected by individual stomatopods when stomatopods could choose from all sizes of burrows. Each burrow consisted of an entrance tunnel and a chamber in a fired ceramic block. Data were analysed with a Spearman rank correlation test to see if stomatopod size was correlated with burrow size $\left(r_{s}=0.74^{\cdots} \cdots, N=36\right)$. Modified from Reaka et al. (unpubl. )

tests provided results similar to those above (Moran 1984), so are nui duplicated here.

Stomatopod size: For the analyses of stomatopod length, a 2-way ANOVA was used to test the relationship between all 5 habitats (IBZ, SFR, PR, BR, FR) and the 2 collecting intervals for which data from all habitats were available (summer 1980, summer 1981). A similar 2-way ANOVA was conducted for 4 habitats (IBZ, SFR, $\mathrm{PR}, \mathrm{BR}$ ) and 3 collecting intervals (summer 1979, summer 1980, summer 1981). If either of the 2-way ANOVAs had significant interaction effects, we planned a 1-way ANOVA on each habitat with collecting intervals as treatments and a similar test on each collecting period with habitats as treatments. When any of these ANOVAs were significant, a Duncan's multiple range test was used. Sample sizes for these tests are given in Table 2. The 2-way and 1-way ANOVAs tested for the effects of Hurricanes David and Frederic of September 1979 (Rogers et al. 1982, 1983, Moran \& Reaka unpubl.) on stomatopod length, and also tested for habitat differences in stomatopod size which could be correlated with habitat differences in mean hole size.

Number of stomatopods: A 1-way ANOVA tested for differences in number of stomatopods rock ${ }^{-1}$ among all 5 habitats in the summer of 1980 . To increase sample sizes, an additional 2-way ANOVA analysed the
Table 2. Sample sizes of treatments for ANOVAs on stomatopod length. Samples from summers 1979, 1980, and 1981 included stomatopods from similar habitats but in areas adjacent to our transects. S79: summer 1979; W79-80: winter 1979-80, S80: summer 1980; W80-81: winter 1980-81; S81: summer 1981

\begin{tabular}{|lrrrrr|}
\hline \multirow{2}{*}{ Habitat } & \multicolumn{5}{c|}{ Collecting interval } \\
& S79 & W79-80 & S80 & W80-81 & S81 \\
\hline Intertidal zone & 146 & - & 8 & 2 & 22 \\
Fringing reef & 114 & 5 & 12 & 14 & 76 \\
Patch reef & 33 & 6 & 8 & 8 & 37 \\
Back reef & 109 & 10 & 22 & 10 & 46 \\
Fore reef & - & - & 12 & 6 & 23 \\
\hline
\end{tabular}

number of stomatopods rock ${ }^{-1}$ among the 5 habitats during 3 collection periods (summer 1980, winter 1980-1981, summer 1981). If the result of the 1 -way ANOVA on stomatopod number was significant, we planned a Duncan's multiple range test. If either of the main effects of the 2-way ANOVA were significant but the interaction effect was not, we planned a Duncan's multiple range test on the treatments for each significant effect.

Significance levels throughout this paper are indicated as follows: no asterisk, $p>0.05 ; \cdot 0.01<p \leq 0.05$; $\cdots 0.001<p \leq 0.01 ; \cdots p \leq 0.001$.

\section{RESULTS}

\section{Analysis of space}

Percentage of substreate bioeroded. The ANOVA indicated that the percentage of substrate removed by bioerosion differed significantly among the habitats. In the summer of 1980 , bioeroders had removed a significantly higher percentage of substrate from rubble on

Table 3. Extent of bioerosion in different habitats (mean \% of total area that was bored on the cut surfaces of the 2 halves of each rock). Holes $<5 \mathrm{~mm}$ diameter were not included in these analyses (see text). Results of 1-way ANOVA: $F_{4,45}=2.65^{\circ}$. No transformation was needed, since $F$ - $\max _{5,9}=1.94$. Each mean of a pair without a common superscript is significantly different from the other at the $p<0.05$ level by a Duncan's multiple range test. $N=10$ for all treatments

\begin{tabular}{|lrr|}
\hline & \multicolumn{2}{c|}{ Percentage of area bored } \\
Habitat & $\bar{Y} \pm \mathrm{SE}$ & \multicolumn{1}{c|}{ Range } \\
\hline Intertidal zone & $8.4^{\mathrm{a}} \pm 2.95$ & $0.16-30.8$ \\
Fringing reef & $13.0^{\mathrm{ab}} \pm 2.41$ & $2.77-27.3$ \\
Patch reef & $18.3^{\mathrm{b}} \pm 2.12$ & $11.90-32.9$ \\
Back reef & $10.5^{\mathrm{a}} \pm 2.51$ & $2.65-29.1$ \\
Fore reef & $9.5^{\mathrm{a}} \pm 2.32$ & $0.92-21.9$ \\
& & \\
\hline
\end{tabular}


the patch reef $(\bar{Y}=18.3 \%)$ than on the back reef, fore reef and intertidal zone (Table 3).

Average sizes of holes. Especially the intertidal zone and fringing reef, but also the fore reef, had significantly larger holes than did the patch reef; the intertidal zone also had significantly larger holes than the back reef (Table 4 ). We had additionally analysed sizes of holes separately for each half of the 10 rocks so that all data within each set would be statistically independent; however, the differences between habitats and significance levels were the same as those pre-

Table 4. Differences in mean hole sizes among habitats. All holes with diameters of $5.06-35.05 \mathrm{~mm}$ from both cut halves of each rock were included (see text) Means, back-transformed $95 \%$ confidence intervals, and sample sizes are given After negative square root transformation $\left((\mathrm{Y}+1)^{-0.5}\right)$, F$\max _{5,48}=1.58$. Data were analyzed by ANOVA $\left(F_{4,1588}=\right.$ $13.0 \cdots)$. Superscripts indicate the results of a Duncan's multiple range test at $p<0.05$

\begin{tabular}{|lccr|}
\hline \multicolumn{4}{c}{ Hole diameter $(\mathrm{mm})$} \\
Habitat & $\overline{\mathrm{Y}}$ & $95 \% \mathrm{CI}$ & \multicolumn{1}{c|}{$N$} \\
\hline Intertidal zone & $10.29^{\mathrm{c}}$ & $(8.83-11.97)$ & 49 \\
Fringing reef & $8.47^{\mathrm{cb}}$ & $(7.94-9.03)$ & 207 \\
Patch reef & $7.37^{\mathrm{a}}$ & $(7.18-7.58)$ & 676 \\
Back reef & $7.71^{\mathrm{ab}}$ & $(7.39-8.05)$ & 322 \\
Fore reef & $8.28^{\mathrm{b}}$ & $(7.93-8.66)$ & 333 \\
\hline
\end{tabular}

sented here, hence data from both cut halves of all rocks are combined for convenience.

Size frequencies of holes. Fig. 3 shows the size frequency distribution of hole diameters on an arithmetic scale and Table 5 presents the results of the statistical tests on these samples. For the smallest size class $(0.00-5.05 \mathrm{~mm})$, the patch reef had significantly more holes than any of the other habitats. Significantly more moderately small holes (5.06-10.05 mm diameter) were found on the patch reef than in any of the other 4 habitats. Also, the back reef had significantly more 5.06-10.05 mm holes than the fringing reef and the intertidal zone. All 4 subtidal habitats had significantly more holes of this size than did the intertidal zone. In the 10.06-15.05 mm range (intermediate sized holes), the patch reef had significantly more holes than did the intertidal zone, fringing reef and back reef; and the back and fore reefs had significantly more holes of this size than did the intertidal zone. Frequencies for relatively large $(15.06-30.05 \mathrm{~mm})$ holes did not differ significantly among habitats. Holes of large size $(>30.05 \mathrm{~mm})$ were most common in the intertidal zone and fringing reef, but became less frequent on the patch reef and bank barrier reef.

In summary, the patch reef had the highest frequency of very small holes ( $\leq 5.05 \mathrm{~mm}$ ), moderately small holes $(5.06-10.5 \mathrm{~mm})$ and holes of intermediate size (10.06-15.05 mm). The fore reef, back reef and fringing reef had intermediate frequencies and the intertidal

Table 5. Results of statistical tests on number of holes of various sizes among habitats. In all cases, arithmetic means are given; respective $95 \%$ confidence intervals are listed in parentheses below the means and are back-transformed when the data were transformed. Multiplicative inverse transformation was $(\mathrm{Y}+1)^{-1}$, negative square root transformation was $(\mathrm{Y}+1)^{-0.5}$, and square root transformation was $(Y+1)^{05}$. Degrees of freedom for $F$-ratios, Kruskal-Wallis $H$-statistics and $F$-max tests are listed in parentheses below the respective test values. For the sake of uniformity, arithmetic means and $95 \%$ confidence intervals are listed for the 10.06-15.05 $\mathrm{mm}$ class of hole size even though this class was analysed non-parametrically. Means without a common superscript are significantly different at the $p<0.05$ level either by a Duncan's multiple range test (for parametric data) or by a Mann-Whitney $U$-test adjusted for multiple comparisons (for non-parametric data). $N=10$ for all treatments in each analysis

\begin{tabular}{|c|c|c|c|c|c|c|c|c|}
\hline \multirow[t]{2}{*}{$\begin{array}{l}\text { Hole diameter } \\
(\mathrm{mm})\end{array}$} & \multicolumn{5}{|c|}{ Habitat } & \multirow[t]{2}{*}{$\begin{array}{l}\text { Transfor- } \\
\text { mation }\end{array}$} & \multirow[t]{2}{*}{$\begin{array}{c}\text { Test } \\
\text { value }\end{array}$} & \multirow[t]{2}{*}{$\begin{array}{c}F_{\text {-max }} \\
\text { test }\end{array}$} \\
\hline & $\begin{array}{l}\text { Intertidal } \\
\text { shore }\end{array}$ & $\begin{array}{l}\text { Fringing } \\
\text { reef }\end{array}$ & $\begin{array}{l}\text { Patch } \\
\text { reef }\end{array}$ & $\begin{array}{l}\text { Back } \\
\text { reef }\end{array}$ & $\begin{array}{l}\text { Fore } \\
\text { reef }\end{array}$ & & & \\
\hline $0.00-5.05$ & $\begin{array}{c}63^{\star} \\
(8.97-117.1)\end{array}$ & $\begin{array}{c}94^{\circ} \\
(7.00-180.6)\end{array}$ & $\begin{array}{c}294^{b} \\
(225.8-362.9)\end{array}$ & $\begin{array}{c}131^{\mathrm{a}} \\
(64.4-198.1)\end{array}$ & $\begin{array}{c}145^{\mathrm{a}} \\
(88.9-200.6)\end{array}$ & - & $\begin{array}{l}F=8.92 \cdots \\
(4,45)\end{array}$ & $\begin{array}{l}2.39 \\
(5.9)\end{array}$ \\
\hline $5.06-10.05$ & $\begin{array}{c}1.5^{\mathrm{a}} \\
(0.34-2.47)\end{array}$ & $\begin{array}{c}6.7^{b} \\
(2.72-10.0)\end{array}$ & $\begin{array}{l}26^{d} \\
(21.6-30.3)\end{array}$ & $\begin{array}{c}13^{c} \\
(8.26-18.0)\end{array}$ & $\begin{array}{c}10^{\mathrm{bc}} \\
(6.57-13.8)\end{array}$ & $\mathrm{Y}^{05}$ & $\begin{array}{l}F=30.90 \cdots \\
(4,45)\end{array}$ & $\begin{array}{l}3.93 \\
(5.9)\end{array}$ \\
\hline $10.06-15.05$ & $\begin{array}{c}0.70^{\mathrm{d}} \\
(0.00-1.58)\end{array}$ & $\begin{array}{c}2.1^{\mathrm{ab}} \\
(1.22-2.88)\end{array}$ & $\begin{array}{c}5.7^{\mathrm{c}} \\
(4.69-6.71)\end{array}$ & $\begin{array}{c}2.9^{\mathrm{b}} \\
(1.34-4.46)\end{array}$ & $\begin{array}{c}4.6^{\mathrm{bc}} \\
(2.46-6.74)\end{array}$ & - & $\begin{array}{l}\mathrm{H}=24.8 \cdots \\
(4)\end{array}$ & $\begin{array}{l}- \\
-\end{array}$ \\
\hline $15.06-20.5$ & $\begin{array}{c}0.70 \\
(0.11-1.29)\end{array}$ & $\begin{array}{c}0.85 \\
(0.44-1.26)\end{array}$ & $\begin{array}{c}1.6 \\
(0.66-2.54)\end{array}$ & $\begin{array}{c}1.2 \\
(0.21-2.09)\end{array}$ & $\begin{array}{c}1.1 \\
(0.28-1.97)\end{array}$ & $\begin{array}{l}- \\
-\end{array}$ & $\begin{array}{l}F=0.10 \\
(4,45)\end{array}$ & $\begin{array}{l}5.13 \\
(5,9)\end{array}$ \\
\hline $20.06-25.05$ & $\begin{array}{c}0.35 \\
(0.01-0.90)\end{array}$ & $\begin{array}{c}0.60 \\
(0.27-0.93)\end{array}$ & $\begin{array}{c}0.55 \\
(0.16-0.94)\end{array}$ & $\begin{array}{c}0.45 \\
(0.09-0.81)\end{array}$ & $\begin{array}{c}0.25 \\
(0.00-0.55)\end{array}$ & - & $\begin{array}{l}F=0.88 \\
(4,45)\end{array}$ & $\begin{array}{l}1.68 \\
(5,9)\end{array}$ \\
\hline $25.06-30.05$ & $\begin{array}{c}0.10 \\
(0.00-0.21)\end{array}$ & $\begin{array}{c}0.40 \\
(0.00-0.58)\end{array}$ & $\begin{array}{c}0.20 \\
(0.00-0.37)\end{array}$ & $\begin{array}{c}0.25 \\
(0.01-0.44)\end{array}$ & $\begin{array}{c}0.25 \\
(0.00-0.44)\end{array}$ & $Y^{-0.5}$ & $\begin{array}{l}F=0.26 \\
(4,45)\end{array}$ & $\begin{array}{l}4.50 \\
(5,9)\end{array}$ \\
\hline$>30.05$ & $\begin{array}{c}0.70^{c} \\
(0.20-1.08)\end{array}$ & $\begin{array}{c}0.50^{\mathrm{bc}} \\
(0.10-0.76)\end{array}$ & $\begin{array}{l}0.20^{a b} \\
(0.01-0.35)\end{array}$ & $\begin{array}{c}0.25^{a b} \\
(0.00-0.35)\end{array}$ & $\begin{array}{c}0.05^{\circ} \\
(0.00-0.12)\end{array}$ & Y & $\begin{array}{l}F=3.77^{\circ} \\
(4,45)\end{array}$ & $\begin{array}{l}5.42 \\
(5,9)\end{array}$ \\
\hline
\end{tabular}




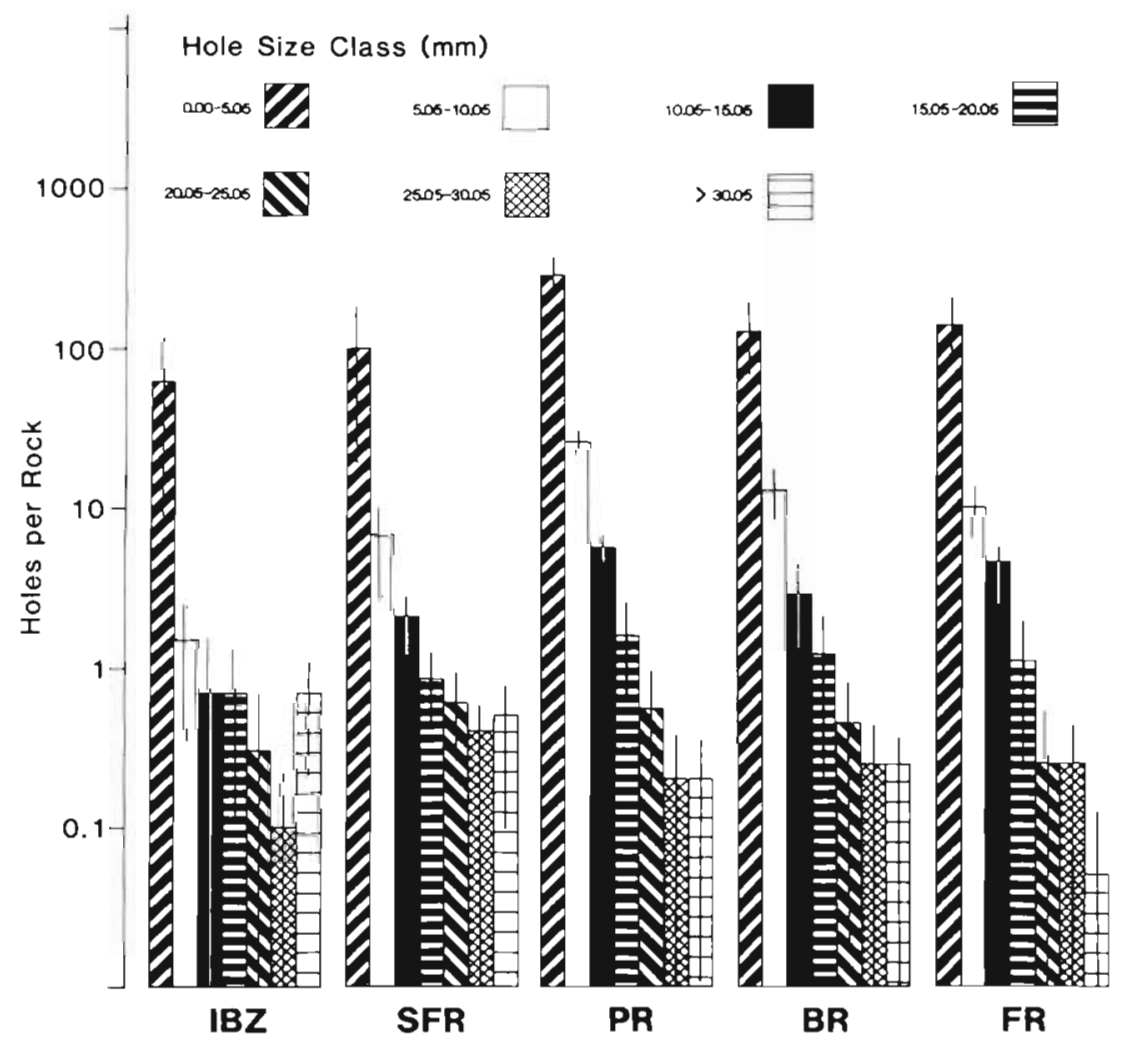

Fig. 3. Size frequency distribution of holes for the intertidal beach rock zone (IBZ), subtidal fringing reef (SFR), patch reef (PR), back reef (BR) and fore reef (FR). Bars of histograms are arithmetic means. Error bars are $95 \%$ confidence intervals, and are backtransformed when necessary after analyses of differences among habitats for each size class. Thus, error bars are not intended for comparisons among size classes within a habitat. Although the $10.06-15.05 \mathrm{~mm}$ size class was analysed non-parametrically, arithmetic means and $95 \%$ confidence intervals are given for the sake of uniformity but not for comparisons among habitats. $N-$ 10 rocks for all size classes in each habitat

zone had the lowest frequency of moderately small and intermediate sized holes. Large holes (>30.05 mm), however, were especially common in the intertidal zone and fringing reef habitats, and declined in frequency toward the bank barrier reef. Rock-boring urchins Echinometra lucunter on the fringing reef of Boiler Bay commonly bore holes 30 to $40 \mathrm{~mm}$ in diameter (Bosence 1984); these urchins were extremely common in the intertidal zone and fringing reef at the time of our study. Some sponges (Cliona, Siphonodyctyon) also form cavities 30 to $50 \mathrm{~mm}$ in diameter (MacGeachy 1977).

For the overall size range of 5.06 to $35.05 \mathrm{~mm}$, the patch reef had significantly more holes rock ${ }^{-1}$ than did the other 4 habitats (Table 6 ). The fringing reef, back reef and fore reef each had significantly more holes rock ${ }^{-1}$ in this range than did the intertidal zone, but they did not differ significantly among themselves. Thus, the habitats can be ranked as follows for number of total holes available for stomatopods: $\mathrm{PR}>\mathrm{BR}=\mathrm{FR}=\mathrm{SFR}>$ IBZ. The number of holes suitable for small stomatopods can be summarized as $\mathrm{PR}>\mathrm{FR}=\mathrm{BR} \geq \mathrm{SFR}>\mathrm{IBZ}$, while those available for large stomatopods were approximately the reverse, $\mathrm{IBZ} \geq \mathrm{SFR} \geq \mathrm{PR}=\mathrm{BR} \geq \mathrm{FR}$.
Table 6. Total number of holes (5.06 to $35.05 \mathrm{~mm}$ diameter) per rock in different habitats. After square root transformation $\left([\mathrm{Y}+1]^{0.5}\right), F_{4,45}=22.6^{\cdots} \cdot$ and $F$ - max $_{5,9}=2.97$. Arithmetic means and back-transformed $93 \%$ confidence intervals are given. Each pair of means without a common superscript are significantly different at the $p<0.05$ level by Duncan's test. $N$ $=10$ for all treatments

\begin{tabular}{|lcc|}
\hline Habitat & \multicolumn{2}{c|}{ No. of holes/rock } \\
& $\overline{\mathrm{Y}}$ & $95 \% \mathrm{CI}$ \\
\hline Intertidal zone & $3.2^{\mathrm{a}}$ & $(0.86-5.4)$ \\
Fringing reef & $11.0^{\mathrm{b}}$ & $(5.8-15.5)$ \\
Patch reef & $34.3^{\mathrm{c}}$ & $(28.6-40.2)$ \\
Back reef & $18.2^{\mathrm{b}}$ & $(10.9-25.2)$ \\
Fore reef & $16.7^{\mathrm{b}}$ & $(9.4-23.3)$ \\
\hline
\end{tabular}

\section{Stomatopod size}

A significant interaction effect $\left(F_{4,256}=3.10^{\circ}\right)$ for all 5 habitats and 2 collecting intervals (summers 1980, 1981) was found for the 2-way ANOVA on stomatopod length. Similarly, a significant interaction effect $\left(F_{6,618}=\right.$ $3.93^{*}$ ) for the 4 habitats (the fore reef was not included) 
Table 7 (a) Differences in body size of stomatopods among habitats for 5 collecting intervals, and (b) differences in these sizes among collecting intervals for 5 habitats. Data were analyzed with 1-way ANOVAs. Sample sizes for all treatments are given in Table 2. Respective $95 \%$ confidence intervals are given in parentheses beneath arithmetic means, and are back-transtormed if the data were transformed. Abbreviations for transformations are as in Table 5. Degrees of freedom are presented in parentheses beneath the respective test statistics (F-ratios, F-max ratios). Each of a pair of means without a common superscript is significantly different from the other by a Duncan's multiple range test $(p<0.05)$

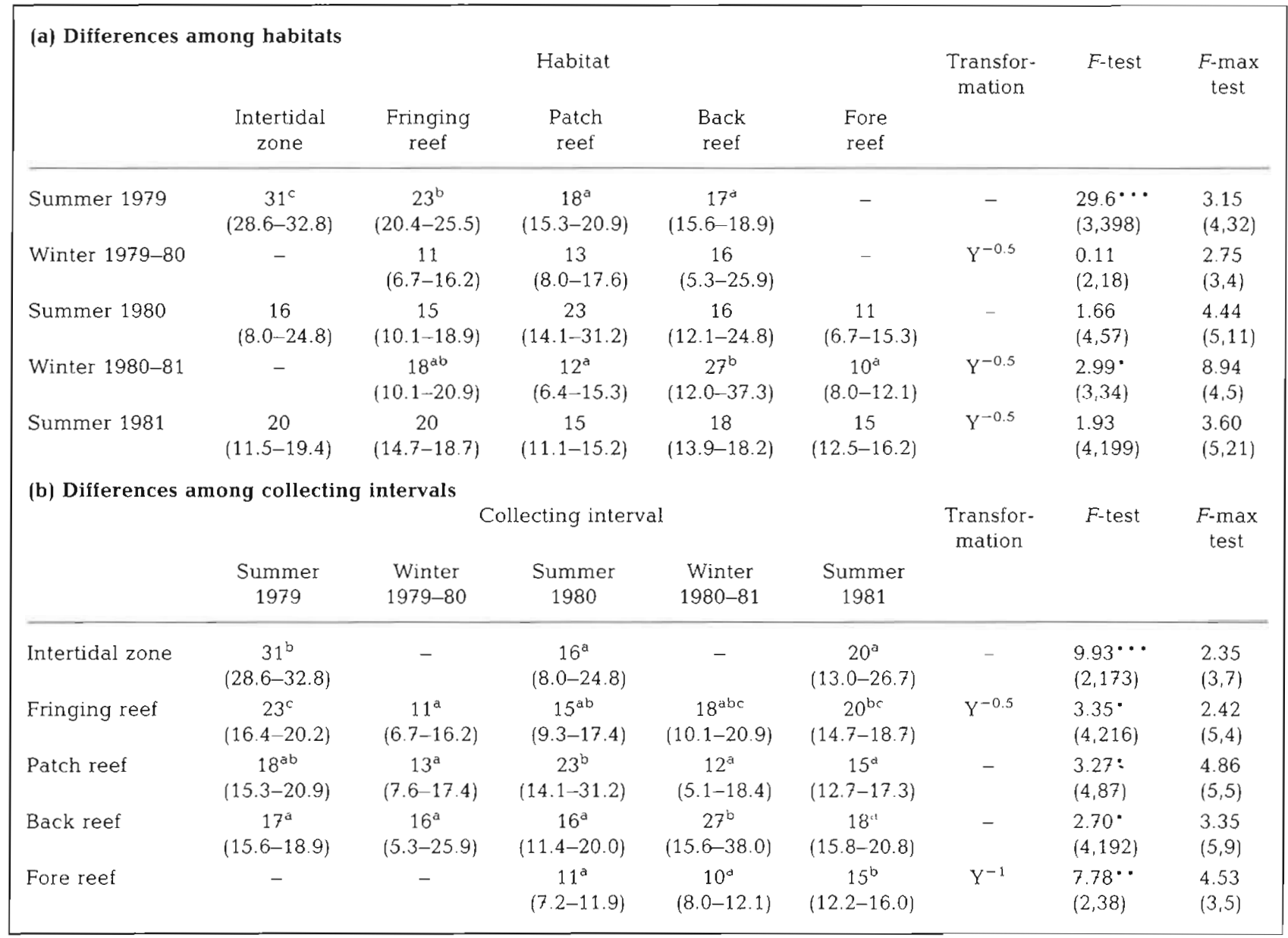

and 3 collecting periods (summers 1979, 1980,1981) was obtained in the 2-way ANOVA on stomatopod length. Therefore, a series of 1-way ANOVAs, one for each habitat, were conducted. Similarly, a series of 1-way ANOVAs were conducted for each collecting interval.

In the summer of 1979 , stomatopods were largest in body size in the intertidal zone, and the patch reef and back reef had the smallest stomatopods (IBZ $>$ SFR $>$ PR

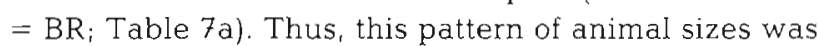
similar to the pattern for average hole size measured in summer 1980 ithe latter was $\mathrm{IBZ} \geq \mathrm{SFR} \geq \mathrm{PR} \geq \mathrm{BR}$; Table 4). In addition, in summer 1980 the intertidal zone and to a lesser extent the fringing reef supported the greatest number of large holes and the fewest small holes (Table 5).

Stomatopod size varied significantly over time in all 5 habitats (Table 7b). Stomatopod populations and burrows were eliminated in the intertidal zone by waves and scouring from Hurricanes David and Frederic in fall 1979 and recovered very slowly (Moran \& Reaka unpubl.). Stomatopods were absent from the intertidal zone in winter 1979-80, and were significantly smaller in subsequent collections there than in summer 1979. Similarly, body size of stomatopods inhabiting the fringing reef decreased significantly after the hurricanes, followed by a slow recovery. Data on body sizes of stomatopods in patch reef and back reef habitats failed to reflect strong or consistent effects of the hurricanes. On the back reef and the fore reef, stomatopod size was significantly larger in winter 1980-81 and summer 1981, respectively, than at any other time, suggesting a late shift from juvenile toward adult populations in these habitats.

When data from adjacent time periods for which mean 
size of stomatopods does not differ significantly are grouped together, the proportion of recently settled individuals (5-10 $\mathrm{mm}$ size class of stomatopods) was low (2 to $16 \%$ ) in shoreward portions of the lagoon (IBZ, SFR, PR) during summer 1979 (Fig. 4a, b, c). In later samples from these habitats, the proportion of recently settled individuals increased ( 13 to $50 \%$, median of 8 samples $=$ $32.5 \%$ ), and often formed the largest size class in the population. The reverse trend is seen on the bank barrier reef, where recently settled individuals formed one of the largest size classes in early sampling (28 to $70 \%$, median of 4 samples $=54 \%$, from summer 1979 to summer 1980), but were proportionately much less abundant ( 9 to $17 \%$ ) in summer 1981 in both back reef and fore reef habitats (Fig. 4d, e). Juveniles may have been excluded from shoreward habitats in early sampling $(1979)$ by cannibalism and competition from large adults, both of which have been documented in stomatopods (Reaka 1987). The elimination of large stomatopods in the shallow shoreward habitats may have allowed postlarvae to differentially settle or survive in shoreward habitats (where fish predation is lower than on the bank barrier reef) following the hurricanes. The trend for increased size of stomatopods from winter 1979-80 to summer 1981 in the intertidal zone and fringing reef habitats suggests that the original size distribution among habitats was beginning to be re-established by the end of our 2 yr study (Table 7b; Fig. 4a, b).

In conclusion, there was a clear trend for body sizes to decrease with increasing distance from shore prior to the hurricanes. This trend was consistent with a pattern of decreasing hole sizes from the intertidal zone to the bank barrier reef in summer 1980. We assume that hole sizes also had been largest in the intertidal habitat during summer 1979. This agrees with our extensive but unquantified observations of porosity in these habitats in 1979, and with the fact that urchins and other large borers had been very abundant in these shallow areas prior to the hurricanes. Since the subtidal habitats suffered minimal erosion during the hurricanes (Moran \& Reaka unpubl.), large holes almost certainly had not been differentially eliminated in the subtidal environments by the storms. These data, then, suggest that one reason that stomatopods can reach large sizes in shallow shoreward areas during prolonged undisturbed periods may be that burrowing organisms (especially Echinometra lucunter) excavate larger holes in this habitat. Subtidal reefward habitats were characterized by smaller holes and smaller stomatopods.

\section{Number of stomapods per rock}

If the number of holes limited the abundance of stomatopods, then the overall density of stomatopods should be correlated with the number of appropriately sizes holes in different habitats $(\mathrm{PR}>\mathrm{FR}=\mathrm{BR}=\mathrm{SFR}>$ IBZ; Table 6).

In summer 1980, there were no significant differences among habitats in the number of stomatopods rock $^{-1}$, but sample sizes were relatively small. In a similar analysis, but using data from summer 1980 through summer 1981 to increase sample sizes (there were no significant differences in number of stomatopods rock ${ }^{-1}$ among these collecting intervals), the intertidal zone was inhabited by significantly fewer stomatopods than the fringing reef, patch reef and back reef (Table 8 ). These data are consistent with the hypothesis that number of holes limited numbers of stomatopods in the intertidal beachrock zone after the hurricanes, when both hole density and stomatopod density were sampled. There was no tendency, however, for unusually high densities of stomatopods to occur in the abundant holes of the patch reef environment. Densities of stomatopods were somewhat lower on the deep fore reef than in the other subtidal reef habitats. These data conform to a nearly universal decline in the abundance of reef stomatopods below - 10 m (Reaka 1980c, Reaka \& Manning 1987a), possibly due to fish predation or low availability of food in deeper habitats (Wolf et al. 1983, Reaka 1985).

\section{DISCUSSION}

\section{Relationship of hole size and number to body size and abundance of stomatopods}

In reef-dwelling ophiuroids, body size correlates with size of the crevice inhabited, and the niche axes that most differentiate species are length and width of burrows occupied (Sides \& Woodley 1985). Body size of stomatopods also is highly correlated with volume of the cavity occupied in the laboratory (Fig. 2; Reaka et al. unpubl.). In addition, the present study shows a positive correlation between stomatopod body size and numbers versus the sizes and numbers of holes available among 5 habitats in the field. This relation is most apparent in intertidal compared to deeper habitats. While these data are consistent with the hypothesis that hole number and size limit the numbers and sizes of coral-dwelling stomatopods, there was less evidence for this relationship among the subtidal habitats. For example, the patch reef, characterized by large numbers of small holes, was not inhabited by unusually dense populations of especially small stomatopods. Other factors, especially in subtidal habitats, may interact with the number and size of holes available to determine the size distributions and densities of the more motile cryptic reef organisms such as stomatopods. 
a Intertidal Zone

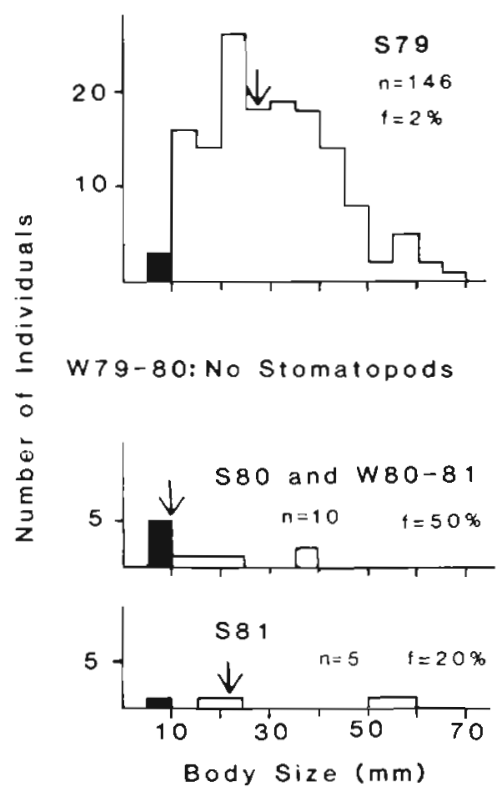

d Back Reef

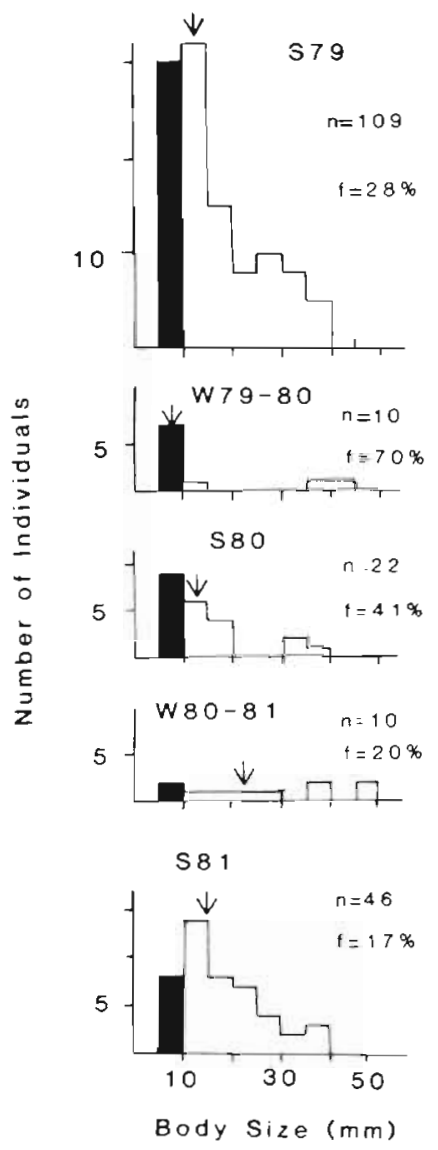

b Fringing Reef
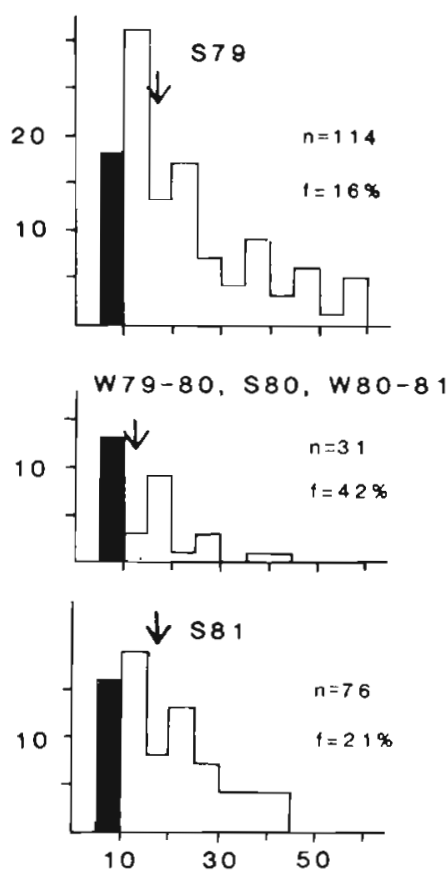

Body Size $(\mathrm{mm})$ c Patch Reef
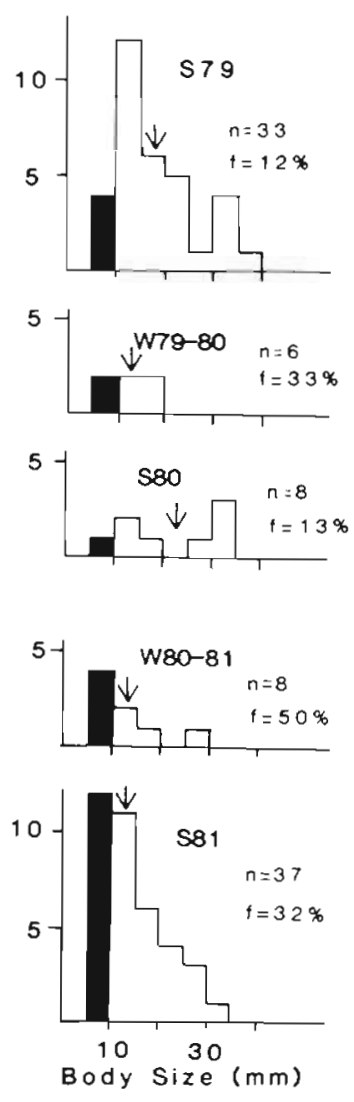

\section{e Fore Reef}
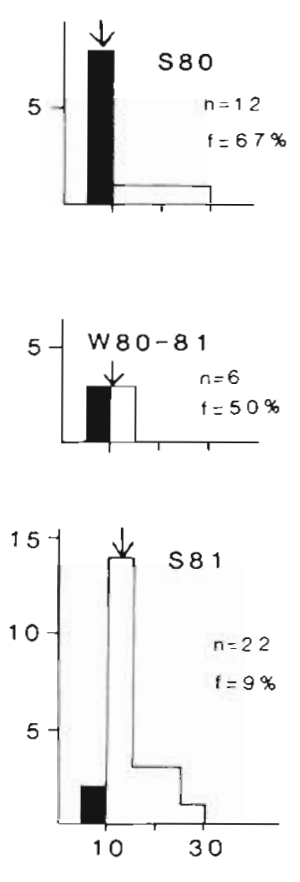

Body Size $(\mathrm{mm})$
Fig. 4. Size frequency distribution of stomatopods from the (a) intertidal zone, (b) fringing reef, (c) patch reef, (d) back reef and (e) fore reef. Arrows indicate median sizes. $n$ : total sample size; $f$ : fraction of total which were postlarvae or recently settled individuals ( $\leq 10 \mathrm{~mm}$ in length, solid bar on histogram). S79: summer 1979; W79-80: winter 1979-80; S80: summer 1980; W80-81. winter 1980-81; S81: summer 1981 
Table 8. Differences in the number of stomatopods per rock among habitats for summer 1980 and for summer 1980 through summer 1981. For S80, data were analysed by 1 -way $A N O V A\left(F_{4,41}=1.80\right)$; no transformation was needed $(F$-rnax $5,8=2.84)$. For S80-81, data were analysed by 2-way ANOVA (season $\times$ habitat) for summer 1980 , winter $1980-81$ and summer 1981 ; after log transformation $(\ln [\mathrm{Y}+1]), F-\max _{12,9}=3.33$. The interaction effect $\left(F_{8,126}=0.97\right)$ and seasonal effect $\left(F_{2,126}=1.82\right)$ were not significant. The habitat effect was $F_{4,126}=3.60^{\circ}$ Arithmetic means of habitats, along with back-transformed $95 \%$ confidence intervals and sample sizes, are reported. Each of a pair of means without a common superscript is significantly different from the other at the $p<0.05$ level by a Duncan's multiple range test

\begin{tabular}{|c|c|c|c|c|c|c|}
\hline \multirow[t]{2}{*}{ Habitat } & \multicolumn{3}{|c|}{ No. of stomatopods rock ${ }^{-1} \mathrm{~S} 80$} & \multicolumn{3}{|c|}{ No. of stomatopods rock ${ }^{-1}$ S80-81 } \\
\hline & $\bar{Y}$ & $95 \% \mathrm{Cl}$ & $N$ & $\bar{Y}$ & $95 \% \mathrm{CI}$ & $N$ \\
\hline Intertidal zone & 0.89 & $(0.00-1.94)$ & 9 & $0.52^{\mathrm{a}}$ & $(0.09-0.48)$ & 29 \\
\hline Fringing reef & 1.20 & $(0.20-2.20)$ & 10 & $1.34^{\mathrm{b}}$ & $(0.69-1.49)$ & 29 \\
\hline Patch reef & 1.00 & $(0.00-2.18)$ & 8 & $1.07^{\mathrm{b}}$ & $(0.48-1.24)$ & 27 \\
\hline Back reef & 2.44 & $(1.11-3.78)$ & 9 & $1.54^{\mathrm{b}}$ & $(0.68-1.72)$ & 26 \\
\hline Fore reef & 1.20 & $(0.46-1.94)$ & 10 & $0.87^{\mathrm{ab}}$ & $(0.36-0.99)$ & 30 \\
\hline
\end{tabular}

One factor that may influence the correlation between stomatopod abundance and the number of available holes is their 'territorial' behavior. The reef stomatopods we studied in St Croix (Gonodactylus oerstedii, G. bredini, G. spinulosus) defend part or an entire piece of rubble, and the defended area often contains a number of burrows (pers. obs., Dominguez \& Reaka 1988). For example, Fig. 3 and Table 6 show that there are more holes in individual rocks than number of stomatopods, especially in subtidal habitats (note that for diameters $>20 \mathrm{~mm}$, however, an average of less than 1 hole rock $^{-1}$ is present; Table 5). We have observed individual stomatopods using a number of different cavitics within their territories as iemporary shelters and feeding, molting, or mating sites. These individuals vigorously exclude all other competitors (stomatopods, crabs, snapping shrimps, etc.) from all of these burrows, even though they must emerge from one cavity and move a considerable distance to attack an intruder entering another hole within their territory. Although stomatopod densities can be altered experimentally in the field by manipulating spatial resources (pieces of rubble with suitable burrows; Reaka 1980b, 1985, Steger 1987), the nature of this agonistic behavior may explain why the relation between numbers of stomatopods in the present study and number of holes available is somewhat weaker than the correlation between body size of stomatopods and size of holes available in different habitats.

We have also used field experiments to demonstrate that fish predation can reduce numbers of stomatopods in subtidal populations (Wolf et al. 1983, Reaka 1985). Fish predation may prevent stomatopods from reaching large sizes in deeper reefward habitats as well. The presence of large (although relatively few) holes in combination with reduced fish predation in intertidal areas may allow stomatopods to attain unusually large sizes there during undisturbed periods (Table 7; Fig. 4).
Furthermore, as shown here and in Moran \& Reaka (unpubl.), occasional violent physical disturbances such as hurricanes can severely affect numbers and sizes of organisms inhabiting cryptic refuges, particularly in shallow habitats such as the intertidal. Cannibalism and competition imposed by large stomatopods probably limited post-larval recruitment in shoreward compared to barrier reef habitats prior to the hurricanes (Reaka 1987). However, the destruction of large stomatopods and the availability of newly bored substrate in the shallow shoreward habitats may have facilitated high recruitment of juvenile stomatopods in these habitats compared to those on the bank barrier reef during the 18 mo after the hurricanes. In some mainland intertidal environments (e.g. grassbeds in Panama), stomatopod densities sometimes fluctuate with seasonal or other physical factors such as extreme tidal exposures (Steger 1987, R. L. Caldwell pers. comm.). In St Croix, however, our analyses of seasonal abundances of all cryptofaunal taxa over 2 yr revealed only a few statistically significant seasonal effects, and we did not detect significant seasonal changes in numbers of reef stomatopods (Moran \& Reaka unpubl.).

Consequently, only during some intervals (i.e. in the absence of disturbances) and only in certain conditions (i.e. reduced fish predation in intertidal areas) do the numbers and sizes of holes limit the numbers and sizes of stomatopods severely and directly. These ecological bottlenecks may nevertheless exert sufficient selective pressure to generate the dramatic behavioral and morphological adaptations that we commonly associate with coral reef organisms (Reaka 1985, 1987). Furthermore, our data suggest that the sizes of cavities available may limit the body sizes of reef-dwelling species, in contrast to stomatopods that excavate enlargeable burrows in level bottoms, and that biogeographic trends in body sizes of assemblages of reef stomatopods (e.g. western Atlantic > eastern Pacific, Australasian > 
central Pacific, high islands > atolls; Reaka 1986a, b, Reaka \& Manning 1987c) are related to the sizes of cavities provided by reef bioeroders

\section{Variation in bioerosion among reef habitats and among biogeographic regions}

The extent and rate of bioerosion sometimes vary considerably among reef habitats (e.g. Scoffin et al. 1980, Spencer 1985). We found more extensive bioerosion (primarily as small holes) in dead coral rubble on the patch reef ( $\bar{Y}=18.3 \%$ volume removed) than in the intertidal zone, the fringing reef, and the back and fore reefs of the bank barrier reef. The greatest extent of bioerosion that has been reported was for a patch reef in Florida (overall $\overline{\mathrm{Y}}=28 \%$ volume eroded in live coral; Hein \& Risk 1975). At Lizard Island on the Great Barrier Reef, Davies \& Hutchings (1983) found a higher rate of initial excavation of cut coral slabs by polychaetes on a lagoonal patch reef than on an adjacent reef flat and fringing reef. After $3 \mathrm{yr}$, however Hutchings \& Bamber (1985) reported lower rates of bioerosion from polychaetes on the patch reef than on the reef flat. In a 3.5 yr study also conducted with dead coral slabs at Lizard Island, Kiene (1985) found that overall rates of bioerosion were intermediate on a lagoonal patch reef site compared to the reef flat and reef slope; however, rates of carbonate production were low in the lagoon, resulting in net carbonate destruction there during one (but not another) year of the study. While the present study showed greatest total bioerosion of patch reef substrate in 1980, the intertidal beachrock zone also was very extensively bored before the hurricanes of 1979 (Moran \& Reaka unpubl.), and still was characterized by particularly large holes during 1980, probably from juvenile rockboring urchins (Echinometra lucunter) as well as large vermiform or sponge burrowers (Bosence 1984). Nevertheless, the rate of bioerosion could be relatively slow in this physically rigorous intertidal habitat, as indicated by the low numbers of small holes a year after the hurricanes (Table 5).

In addition to the above information on bioerosion of patch reefs, a few data are available for comparisons of bioerosion on fringing versus offshore bank reefs. We did not find a significant difference between the extent of bioerosion in dead coral on the fringing reef $(\bar{Y}=13 \%$ excavated) and the offshore bank barrier reef ( $\bar{Y}=9$ to $11 \%$ removed). In contrast, MacGeachy \& Stearn (1976) and MacGeachy (1977) reported more bioerosion in live coral on an offshore bank reef than on a fringing reef $(\bar{Y}$ $=20 \%$ and $5 \%$ volume removed, respectively) at Barbados, possible due to greater age of the corals on the bank reef (MacGeachy \& Stearn 1976)
In subtidal habitats, depth often does not appear to affect bioerosion. We detected no difference in the extent of bioerosion between the shallow back reef $(-3 \mathrm{~m})$ and the fore reef slope $(-12 \mathrm{~m})$ of the bank barrier reef. Other workers also have found no effect of depth upon the rate or extent of bioerosion on a fringing reef (Curaçao; Bak 1976) and on an atoll (Enewetak; Highsmith 1981). At Lizard Island, Davies \& Hutchings (1983) reported similar rates of excavation for polychaetes colonizing coral slab substrates in shallow $(-1$ to $-3 \mathrm{~m})$ and deep $(-12 \mathrm{~m})$ sites on a fringing reef; longer studies at Lizard Island (Hutchings \& Bamber 1985, Kiene 1985) also failed to show a consistent relationship between boring by polychaetes and depth $(-1.5$ to $-18 \mathrm{~m})$. In other cases where the extent of infaunal bioerosion increased with depth (Goreau \& Hartman 1963, MacGeachy \& Stearn 1976), the age of the corals (MacGeachy \& Stearn 1976) and the percentage of dead area (Goreau \& Hartman 1963, Highsmith 1981) also increased with depth, and may have been causal factors. Kiene's (1985) experimental data suggest a possible correlation between depth and rate of excavation in coral slabs by worms, sponges and molluscs; in addition, bioerosion from grazing fishes (urchins were rare in this Great Barrier Reef study) increased dramatically from the reef flat to the lagoonal patch reef to the reef slope. The latter pattern may be prevalent wherever increasing abundances of fishes in deeper water are not compensated by high abundance of urchins in shallow water. Therefore, even though differences in extent and rate of bioerosion exist, few if any general conclusions can yet be drawn about the relationship of particular reef habitats to bioerosion.

On a broader scale, however, the extent of bioerosion does appear to vary between the West Atlantic and the West Pacific. We found that cross sections of dead coral rubble from 5 habitats in St. Croix had a relatively high percentage of their volume bioeroded. Means ranged from 8.4 to $18.3 \%$ among habitats, while the range for individual rocks was 0.16 to $32.9 \%$. At Enewetak, Highsmith (1981) found a mean of $5.5 \%$ area of dead coral rubble eroded, with a range of 1.8 to $11.4 \%$ for individual rocks $N=11$ ). Highsmith X-rayed slabs of constant thickness, so the percentage of area burrowed was the same as the percentage of volume removed from each cross section, as in the present study We found considerably more bioerosion at this Caribbean site than Highsmith found in the West Pacific even though he included all holes and we did not include those less than $20 \mathrm{~mm}^{2}$.

In another study we intend to review geographic patterns in bioerosion and document that the extent and rate of bioerosion in live coral also are significantly higher in the West Atlantic than in the West Pacific 
(Reaka et al. unpubl.). In particular, sponges and boring and scraping urchins exert significantly greater effects on coral substrates in the West Atlantic than in the West Pacific. In accordance with the observations of Risk \& Sammarco (1982) that bioerosion is much more extensive inside than outside damselfish territories, it is tempting to hypothesize that territorial damselfishes may be more dense or widespread, promoting more bioerosion, on West Atlantic than West Pacific reefs. Increased settlement of invertebrate larvae is frequently observed within damselfish territories from which other fishes are excluded (Lobel 1980, Sammarco \& Carleton 1982, Hixon 1983). Furthermore, components of the fish fauna may be heavily exploited by humans in many Caribbean sites, including some parts of St Croix (Ogden et al. 1973, Hay 1984). Thus settling invertebrate larvae (including boring species) may experience lower predation and higher survivorship in many West Atlantic sites compared to areas with less disturbed faunas. Low levels of fish predation also may explain the high densities of burrowing and scraping urchins (Hay 1984, Hay \& Taylor 1985) known in the Caribbean until recently (Lessios et al. 1984).

Possibly damselfishes, urchins, and bioeroders are all relatively abundant in the West Atlantic because primary productivity is greater there than in the West Pacific. Based on his analysis of the incidence of boring bivalves and several other boring or nestling planktivores inhabiting live corals from different biogeographic regions (eastern Pacific > western Atlantic > Indian Oceari > western Pacific) and on data from Koblenz-Mishke et al. (1970) on gross primary productivity of the world's oceans (which follows a similar pattern), Highsmith (1980) hypothesized that worldwide patterns of bioerosion are due to limitation of major bioeroders such as filter-feeding sponges and bivalves by available plankton. The present study confirms that this geographic pattern for bioeroders also holds for dead coral substrates and is consistent with his interpretation. In addition, we suggest that complex interactions between bioeroders and other components of the reef fauna - especially damselfishes, other herbivorous and predacious fishes, and urchins - need to be examined.

Burrowers and other relatively immotile cryptofauna are protected from fish predators by their carbonate surroundings (Wolf et al. 1983, Reaka 1985; see also Jackson \& Buss 1975 and Jackson 1977 for sessile cryptic organisms). Consequently, their numbers in individual rocks often may be limited by food in addition to the availability of spatial resources (e.g. Buss 1979); this conforms with Highsmith's productivity hypothesis for bioeroders (above). In contrast to sedentary cryptofauna, however, larger and more active cryptic species are strongly influenced by fish preda- tors, especially in deep habitats (Wolf et al. 1983, Reaka 1985). Spatial refuges from predators (but not food) limit these large more motile cryptic species (Reaka $1980 \mathrm{~b}, 1985)$, as is also supported by the interhabitat correlations between sizes and numbers of holes and stomatopods in the present study. Thus, the provision of 3-dimensional refuge space by borers is a prerequisite for the development of a diverse and abundant cryptofauna.

\section{Paleobiological significance of bioerosion}

Bioeroders produce prodigious amounts of silt, sand and collapsed coral rubble that smother, abrade and crush other organisms, often governing the structure of entire reef communities (e.g. Scoffin 1972, Woodley et al. 1981, Hubard 1986). The subsequent sessile and motile cryptofauna is one of the most important components of the reef ecosystem in terms of biomass and diversity (Hutchings 1986, Reaka unpubl.), and represents a critical pathway by which nutrients are transferred from primary producers to pelagic consumers (Randall 1967, Grigg et al. 1984, Parrish et al. 1985, Reaka 1985). Thus, these boring, sessile and motile cryptic organisms are crucial elements of the diverse, productive and rapid nutrient cycling communities we know as coral reefs today, and their importance has almost certainly been under-appreciated.

The significance of bioeroders in the evolutionary history of reefs also has not been widely recognized. Although present since the Lower Cambrian (James et al. 1977), burrowers of hard substrates diversified during the Mesozoic (Palmer 1982). Carbonate substrates were vastly amplified by the development of scleractinian corals during the Mesozoic (Newell 1971), and a battery of fast and efficient predators (including fishes, crustaceans and molluscs) were also developing during the Mesozoic (Ogden \& Lobel 1978, Tyler 1980, Reaka $\&$ Manning 1987a). Current work on both intertidal and subtidal hard substrates indicates that a 3-dimensional cryptic environment is essential for the survival of tropical benthic invertebrate assemblages that face large, fast and efficient predators (Menge \& Lubchenco 1981, Reaka 1985). If the numbers and sizes of motile cryptic reef organisms are limited by the numbers and sizes of holes in the substrate as we suggest in the present paper, these results indicate that the cryptic biota also may have proliferated during the Mesozoic in response to increased availability of refuges in the substrate that were provided by the evolving burrowers.

In conclusion, predation likely had a cascading effect upon the development of high species diversity on coral reefs by initially fostering burrowing; the resultant 3-dimensional environment allowed the evolution- 
ary radiation of a vast assemblage of benthic reef biota which also was molded by predation and thence by competition for cryptic spatial refuges.

Acknowledgement. We thank Drs G. J. Vermeij and J. O. Corliss for comments on a previous version of this manuscript, and gratefully acknowledge support from the National Science Foundation (Biological Oceanography) and the National Oceanographic and Atmospheric Administration (Undersea Research Program). This is Contribution No. 160 from the West Indies Laboratory.

\section{LITERATURE CITED}

Adey, W. H. (1978). Coral reef morphogenesis: a multidimensional model. Science 202: 831-837

Adey, W. H., Steneck, R. S. (1985). Highly productive eastern Caribbean reefs: synergistic effects of biological, chemical, physical and geological factors. In: Reaka, M. L. (ed.) The ecology of coral reefs. NOAA Symp. Ser. Undersea Res., Vol. 3. Rockville, Md., p. 163-187

Bak, R. P. M. (1976). The growth of coral colonies and the importance of crustose coralline algae and burrowing sponges in relation with carbonate accumulation. Neth. J. Sea Res. 10: 285-337

Bosence, D. W. (1984). Construction and preservation of two modern coralline algal reefs, St. Croix, Caribbean. Paleontology $27: 549-574$

Buss, L. W. (1979). Bryozoan overgrowth interactions - the interdependence of competition for space and food. Nature, Lond. 281. 475-477

Caldwell, R. L., Dingle, H. (1975). Ecology and evolution of agonistic behavior in stomatopods. Naturwissenschaften 62: $214-222$

Carriker, M. R., Smith, E. H. (1969). Comparative calcibiocavitology: summary and conclusions. Am. Zool. 9: $1011-1020$

Davies, P. J. (1983). Reef growth. In: Barnes, D. J. (ed.) Perspectives on coral reefs. Aust. Inst. Mar. Sci., Townsville, p. 69-106

Davies, P. J., Hutchings, P. A. (1983). Initial colonization, erosion, and accretion of coral substrate. Coral Reefs 2: $27-35$

Dingle, H., Caldwell, R. L. (1972). Reproductive and maternal behavior of the mantis shrimp Gonodactylus bredini Manning (Crustacea: Stomatopoda). Biol. Bull. mar. biol. Lab., Woods Hole 142: 417-426

Dominguez, J. H., Reaka, M. L. (1988). Temporal activity patterns in reef-dwelling stomatopods: a test of alternative hypotheses. J. exp. mar. Biol. Ecol. (in press)

Goreau, T F., Hartman, W. D. (1963). Boring sponges as controlling factors in the formation and maintenance of coral reefs. In: Sognnaes, R. F. (ed.) Mechanisms of hard tissue destruction. Am. Ass. Advmt Sci., Washington, D. C., Pub. No. 75, 25-54

Grigg, R. W., Polovina, J. J., Atkinson, M. J. (1984). Model of a coral reef ecosystem. III. Resource limitation, community regulation, fisheries yield and resource management. Coral Reefs 3: 23-27

Grunbaun, H., Bergman, G., Abbott, D. P., Ogden, J. C (1978). Intraspecific agonistic behavior in the rock-boring sea urchin Echnometra Jucunter (L.) (Echinodermata; Echinoidea). Bull. mar. Sci. 28: 181-188

Hay, M. E. (1984). Patterns of fish and urchin grazing on
Caribbean coral reefs: are previous results typical? Ecology 65: 446-4.54

Hay, M. E., Taylor, P. R. (1985). Competition between herbivorous fishes and urchins on Caribbean reefs. Oecologia (Berl.) 65: 591-598

Hein, F. J., Risk, M. J. (1975). Bioerosion of coral heads: inner patch reefs, Florida Reef Tract. Bull. mar. Sci. 25: 133-138

Highsmith, R. C. (1980). Geographic patterns of coral bioerosion: a productivity hypothesis. J. exp. mar. Biol. Ecol. 46 $177-196$

Highsmith, R. C. (1981). Coral erosion at Enewetak: agents and dynamics. Int Revue ges. Hydrobiol. 65: 335-375

Highsmith, R. C., Lueptow, R. L., Schonberg, S. C. (1983) Growth and bioerosion of three massive corals on the Belize barrier reef. Mar. Ecol. Prog. Ser. 13: 261-271

Hixon, M. A. (1983). Fish grazing and community structure of reef corals and algae: a synthesis of recent studies. In Reaka, M. L. (ed.) The ecology of deep and shallow coral reefs. NOAA Symp. Ser. Undersea Res., Vol. 1. Rockville, Md., p. 79-87

Hubbard, D. K. (1986). Sedimentation as a control of reef development: St Croix, U. S. V. I. Coral Reefs 5: 117-125

Hutchings, P. A. (1986). Biological destruction of coral reefs: a review. Coral Reefs 4: 239-252

Hutchings, P. A., Bamber, L. (1985). Variability of bioerrosion rates at Lizard Island, Great Barrier Reef: preliminary attempts to explain these rates and their significance. Proc. 5th Int. Coral Reef Congr. 5: 333-338

Jackson, J. B. C (1977). Competition on marine hard substrata: the adaptive significance of solitary and colonial strategies. Am. Nat. 111: 743-767

Jackson, J. B. C., Buss, T (1975). Allelopathy and spatial competition among coral reef invertebrates. Proc. natl Acad. Sci. U. S. A. 72: 5160-5163

James, N. P., Kobluk, D. R., Pemberton, S. G. (1977). The oldest macroborers: Lower Cambrian of Labrador. Science 197: 980-983

Kiene, W. E. (1985). Biological destruction of experimental coral substrates at Lizard Island (Great Barrier Reef, Australial. Proc. 5th Int. Coral Reef Congr. 5: 339-344

Koblentz-Mishke, O. J., Volkovinsky, V V., Kabanova, J. G. (1970). Plankton primary production of the world, ocean. In: Wooster, W. S. (ed.) Scientific exploration of the South Pacific. Natn. Acad. Sci, Washington, D. C., p. 183-193

Lessios, H. A., Robertson, D. R., Cubit, J. D. (1984). Spread of Diadema mass mortality through the Caribbean. Science 226: $335-337$

Lobel, P. S. (1980). Herbivory by damselfishes and their role in coral reef community ecology. Bull. mar. Sci. 30: 273-289

MacGeachy, J. K. (1977). Factors controlling sponge boring in Barbados coral reefs. Proc. 3rd Int. Coral Reef Symp. 2: $477-483$

MacGeachy, J. K., Stearn, C. W. (1976). Boring by macroorganisms in the coral Montastrea annularis on Barbados reefs. Int. Revue ges. Hydrobiol. 61: 715-745

Menge, B. A., Lubchenco, J. (1981). Community organization in temperate and rocky intertidal habitats: prey refuges in relation to comsumer pressure gradients. Ecol. Monogr 51. $429-450$

Moran, D. P. (1984). The effects of hurricanes and bioerosion upon benthic communities on coral reefs. M. Sc. thesis, Dept Zool., Univ. of Maryland, College Park

Neumann, A. C. (1966). Observations on coastal erosion in Bermuda and measurements of the boring rate of the sponge, Cliona lampa. Limnol. Oceanogr. 11 92-108

Newell, N. D. (1971). An outline history of tropical organic reefs. Am. Mus. Novit. 2465: 1-37 
Ogden, J. C., Brown, R. A., Salesky, N. (1973). Grazing by the echinoid Diadema antillarum Philippi: formation of halos around West Indian patch reefs. Science 182: 715-717

Ogden, J. C., Lobel, P. S. (1978). The role of herbivorous fishes and urchins in coral reef communities. Environ. Biol. Fish. 3: 49-63

Palmer, T I. (1982). Cambrian to Cretaceous changes in background communities. Lethaia 15: 309-323

Parrish, J. D., Callahan, M. W., Norris, J. E. (1985). Fish trophic relationships that structure reef communities. Proc. 5th Int. Coral Reef Congr. 4: 73-78

Randall, J. E. (1967). Food habits of reef fishes of the West Indies. Stud. Trop. Oceanogr. 5: 665-847

Reaka, M. L. (1975). Molting in stomatopod crustaceans: stages of the molt cycle, setagenesis, and morphology J. Morphol. 146: 55-80

Reaka, M. L. (1976). Lunar and tidal periodicity of molting and reproduction in stomatopod Crustacea: a selfish herd hypothesies. Biol. Bull mar. biol. Lab., Woods Hole 150: $468-490$

Reaka, M. L. (1979a). The evolutionary ecology of life history patterns in stomatopod Crustacea. In: Stancyk, S. (ed.) Reproductive ecology of marine invertebrates. Belle $W$ Baruch Library Mar. Sci., Univ. S. Carolina Press, Columbia, p. 235-260

Reaka, M. L. (1979b). Patterns of molting frequencies in coraldwelling stomatopod Crustacea. Biol. Bull. mar. biol. Lab. Woods Hole 156: $328-342$

Reaka, M. L. (1980a). On learning and living in holes by mantis shrimps. Anim. Behav. 28: 111-115

Reaka, M. L. (1980b). Resource limitation in mobile cryptic species: food or space? Am. Zool. 20:885

Reaka, M. L. (1980c). Geographic range, life history patterns, and body size in a guild of coral-dwelling mantis shrimps. Evolution 34: 1019-1030

Reaka, M. L. (1985). Interactions between fishes and motile benthic invertebrates on reefs: the significance of motility vs. delensive adaptations. Proc. 5th Int. Coral Reef Congr 5: $439-444$

Reaka, M. L. (1986a). Biogeographic patterns of body size in stomatopod Crustacea: ecological and evolutionary consequences. In: Heck, K. Gore, R. (eds.) Biogeography of the Crustacea. Balkema Press, Rotterdam, p. 209-235

Reaka, M. L. (1986b). Island endemism, life histories, and evolution of Pacific crustaceans. 2nd Int. Symp. Indo-Pac. Mar. Biol. Prog./Ab.: 28

Reaka, M. L. (1987). Adult-juvenile interactions in benthic reef crustaceans. Bull. mar. Sci. 41: 108-134

Reaka, M. L., Manning, R. B. (1981). The behavior of stomatopod Crustacea, and its relationship to rates of evolution. J. Crust. Biol. 1: 309-327

Reaka, M. L., Manning, R. B. (1987a). The significance of body size, dispersal potential, and habitat for rates of morphological evolution in stomatopod Crustacea. Smithson. Contr. Zool. 448: 1-46

Reaka, M. L., Manning, R. B. (1987b). Techniques for sampling Stomatopoda in benthic environments. Boll. Zool. (in press)

Reaka, M. L., Manning, R. B. (1987c). The stomatopod Crustacea of Enewetak Atoll. In: Devaney, D. M., Reese, E. S., Burch, B. L., Helfrich, P. (eds.) The natural history of
Enewetak Atoll, Vol. 2. Technical Information Center U. S. Dept Energy, Washington, D. C., p. 181-190

Reaka, M. L., Manning, R. B., Felder, D. L. (1987). The signifance of macro- and microhabitat for reproduction in reefdwelling stomatopods from Belize. Boll. Zool. (in press)

Risk, M. J., Sammarco, P. W (1982). Bioerosion of corals and the influence of damselfish territoriality a preliminary study. Oecologia (Berl.) 52: 376-380

Rogers, C. S., Gilnack, M., Fitz, H. C., III (1983). Monitoring of coral reefs with linear transects: a study of storm damage. J. exp. mar Biol. Ecol. 66: 285-300

Rogers, C. S., Suchanek, T H., Pecora, F. A. (1982). Effects of hurricanes David and Frederic (1979) on shallow Acropora palmata reef communities: St. Croix, U. S. Virgin Islands. Bull. mar. Sci. 32: 532-548

Sammarco, P. W., Carleton, J. H. (1982). Damselfish territoriality and coral community structure: reduced grazing, coral recruitment, and effects on coral spat. Proc. 4th Int Coral Reef Symp. 2: 525-535

Scoffin, T. P. (1972). Fossilization of Bermuda patch reefs. Science 178: 1280-1282

Scoffin, T. P., Stearn, C. W., Boucher, D., Frydl, P., Hawkins, C. M., Hunter, I. G., MacGeachy, J. K. (1980). Calcium carbonate budget of a fringing reef on the West Coast of Barbados. Part II: erosion, sediments and internal structure. Bull. mar. Sci. 30: 475-508

Sides, E. M., Woodley, J. D. (1985). Niche separation in three species of Ophiocoma (Echinodermata: Ophiuroidea) in Jamaica, West Indies. Bull. mar. Sci. 36: 701-715

Spencer, T (1985). Marine erosion rates and coastal morphology of reef limestones on Grand Cayman Island, West Indies. Coral Reefs 4: 59-70

Steger, R. (1987). Effects of refuges and recruitment on gonodactylid stomatopods, a guild of mobile prey. Ecology 68: $1520-1533$

Stewart, K. W. (1975). An improved elutriator for separating stream insects from stony suhstrates. Trans. Am. Fish. Soc. 104: 821-823

Swinchatt, J. (1965). Significance of constituent composition, texture, and skeletal breakdown in some recent carbonate sediments. J. Sedim. Petrol. 35: 71-90

Thayer, C. W (1979). Biological bulldozers and the evolution of marine benthic communities. Science 203: 458-461

Tyler, J. C (1980). Osteology, phylogeny and higher classification of the fishes of the order Plectognathi (Tetradontiformes). NOAA Tech. Rept., Nat. Mar. Fish. Serv. Circ. 434: $1-422$

Vermeij, G. J. (1978). Biogeography and adaptation: patterns of marine life. Harvard Univ. Press, Cambridge, Mass.

Wolf, N. G., Bermingham, E. B., Reaka, M. L. (1983). Relationships between fishes and mobile benthic invertebrates on coral reefs. In: Reaka, M. L. (ed.) The ecology of deep and shallow coral reefs. NOAA Symp. Ser. Undersea Res. Vol. 1. Rockville, Md., p. 89-96

Woodley, J. D., Chornesky, E. A., Clifford, P. A., Jackson, J. B. C., Kaufman, L. S., Knowlton, N., Lang, J. C., Pearson, M. P., Porter, J. W., Rooney, M. C., Rylaarsdam, K. W., Tunnicliffe, V. J., Wahle, C. M., Wulff, J. L., Curtis, A. S. G., Dallmeyer, M. D., Jupp, B. P., Koehl, M. A. R., Neigel, J., Sides, E. M. (1981). Hurricane Allen's impact on Jamaican coral reefs. Science 214: 749-755

This article was presented by Professor C. Birkeland; it was accepted for printing on February 18, 1988 